ANUVA Volume 1 (2): 133-138, 2017

Copyright (C2017, ISSN: 2598-3040 online

Available Online at: http://ejournal.undip.ac.id/index.php/anuva

\title{
Kemampuan Komunikasi Interpersonal Pustakawan (Studi di Dinas Kearsipan dan Perpustakaan Provinsi Kepulauan Bangka Belitung)
}

\author{
Ika Krismayani ${ }^{1 *}$ \\ ${ }^{1}$ Program Studi Ilmu Perpustakaan, Fakultas Ilmu Budaya, Universitas Diponegoro \\ *)Korespondensi: ika.krismayani@live.undip.ac.id
}

\begin{abstract}
In the library world, service is the spearhead of the library. Whether or not a library depends on how it works. Librarians are direct actors of service activities. This makes librarians must interact directly with the user so that interpersonal communication skills are needed by the librarian in his effort to establish good interaction with the user, fostering a harmonious relationship with the user to create a comfortable atmosphere in the library. Seeing the general condition that the communication skills of librarians to user still not good, then this paper will discuss about the interpersonal communication skills of librarians in the Archives and Library of Islands Province of Bangka Belitung Islands. The results showed that librarians in the Archives and Library Province of Bangka Belitung Islands had good interpersonal communication skills which were shown by emphaty attitude, supportiveness, positiveness, equality, convidence, immediacy and interaction management.
\end{abstract}

Keywords: communication skills of librarians, interpersonal skills of librarians, regional libraries

\begin{abstract}
Abstrak
Dalam dunia perpustakaan, pelayanan merupakan ujung tombak perpustakaan. Baik tidaknya suatu perpustakaan bergantung pada bagaimana pelayanannya. Pustakawan adalah pelaku langsung kegiatan layanan. Hal tersebut membuat pustakawan harus berinteraksi secara langsung dengan pemustaka sehingga keterampilan komunikasi interpersonal sangat dibutuhkan oleh pustakawan dalam usahanya untuk menjalin interaksi yang baik dengan pemustaka, membina hubungan yang harmonis dengan pemustaka hingga tercipta atmosfer yang nyaman di perpustakaan. Melihat kondisi secara umum bahwa kemampuan komunikasi pustakawan kepada pemustaka masih dirasa kurang baik, maka tulisan ini akan membahas tentang keterampilan komunikasi interpersonal pustakawan di Dinas Kearsipan dan Perpustakaan Provinsi Kepulauan Bangka Belitung. Hasil penelitian menunjukkan bahwa pustakawan di Dinas Kearsipan dan Perpustakaan Provinsi Kepulauan Bangka Belitung telah memiliki keterampilan komunikasi interpersonal yang baik yang ditunjukkan dengan dimilikinya sikap emphaty, supportiveness, positiveness, equality, convidence, immediacy dan interaction management.
\end{abstract}

Kata kunci: keterampilan komunikasi pustakawan, keterampilan interpersonal pustakawan, perpustakaan daerah

\section{Pendahuluan}

Perpustakaan adalah pusat informasi, perannya ditengah masyarakat adalah sebagai lembaga yang menyediakan jasa layanan informasi. Seperti disebutkan dalam Undang-Undang RI No. 43 Tahun 2007 tentang Perpustakaan, yang dimaksud dengan perpustakaan adalah "institusi pengelola karya tulis, karya cetak dan atau karya rekam secara profesional dengan sistem yang baku guna memenuhi kebutuhan pendidikan, penelitian, pelestarian, informasi, dan rekreasi para pemustaka". 
Berdasarkan pengertian perpustakaan tersebut dapat dikatakan bahwa perpustakaan merupakan suatu institusi yang memberikan layanan jasa penyedia informasi (information provider) bagi masyarakat. Jika berbicara tentang layanan, maka hal terpenting yang menjadi dasar dari kegiatan perpustakaan adalah kegiatan pelayanan. Baik maupun buruknya pemberian layanan yang diberikan tergantung kepada pemberi layanan itu sendiri, dalam hal ini adalah pustakawan. Layanan yang diberikan dapat berkualitas manakala pustakawan tersebut memiliki kualitas yang baik pula di dalam dirinya. Kualitas diri yang baik, dipengaruhi oleh latar belakang pendidikannya, kepribadiannya dan juga oleh kemampuannya dalam berkomunikasi.

Salah satu aspek yang mempengaruhi kepuasan pemustaka akan layanan yang diberikan oleh pustakawan adalah ketika pustakawan tersebut memiliki keterampilan komunikasi interpersonal yang baik. Hal tersebut cukup beralasan, karena seperti kita tahu bahwa pekerjaan yang dilakukan oleh pustakawan sebagian besar adalah kegiatan pemberian layanan kepada pemustaka. Seperti dalam Soeatminah (1992:129) disebutkan bahwa dalam dunia perpustakaan, pelayanan merupakan ujung tombak perpustakaan. Baik tidaknya suatu perpustakaan bergantung pada bagaimana pelayanannya, karena bagian layanan inilah yang berhubungan langsung dengan para pengguna perpustakaan. Di sisi lain, pustakawan adalah pelaku langsung kegiatan layanan, sehingga kualitas pustakawan akan berpengaruh pada kualitas layanan perpustakaan. Hal tersebut tentu saja membuat pustakawan harus berinteraksi secara langsung dengan pemustaka sehingga keterampilan komunikasi interpersonal sangat dibutuhkan oleh pustakawan dalam usahanya untuk menjalin interaksi yang baik dengan pemustaka, membina hubungan yang harmonis dengan pemustaka hingga tercipta atmosfer yang nyaman di perpustakaan sehingga pemustaka akan selalu merujuk ke perpustakaan untuk memenuhi kebutuhan informasinya. Dengan demikian keterampilan komunikasi interpersonal yang baik dan efektif sangat penting bagi para pustakawan, agar mereka dapat menjadi pustakawan professional yang dapat memberikan layanan prima (excellent service) kepada para pemustaka. Karena pentingnya keterampilan kemunikasi interpersonal dalam sebagian besar kegiatan pustakawan, maka penulis ingin melakukan penelitian mengenai ketrampilan komunikasi interpersonal pustakawan di Dinas Kearsipan dan Perpustakaan Provinsi Kepulauan Bangka Belitung.

Perpustakaan adalah tempat untuk mencari dan mendapatkan informasi yang diperlukan. Sebagai pusat informasi, di perpustakaan akan selalu terjadi komunikasi di dalam proses penelusuran informasi. Komunikasi tersebut terjadi antara pustakawan (dalam hal ini sebagai komunikator) dan pemustaka (sebagai komunikan). Komunikasi adalah pengiriman dan penerimaan pesan atau berita antara dua orang atau lebih sehingga pesan yang dimaksud dapat dipahami (KBBI, 2007:585). Dari definisi tersebut dapat dikatakan bahwa perpustakaan dan komunikasi adalah dua hal yang saling berkaitan, tidak dapat dipisahkan, keduanya saling membutuhkan untuk menyambung informasi kepada pemustaka. Dalam hal ini, yang paling berperan dalam proses transfer informasi dari perpustakaan kepada pemustaka adalah pustakawan, karena ia adalah penentu keberhasilan apakah transfer informasi tersebut berjalan dengan lancar atau tidak. 
Peran pustakawan tidak hanya berhenti pada pemberi informasi semata, namun pustakawan profesional dituntut untuk dapat bersosialisasi, berinteraksi dan berkomunikasi dengan baik, santun, ramah, berwawasan luas dan dapat memahami kebutuhan pemustaka. Keterampilan berkomunikasi yang baik sangat diperlukan agar pemustaka mendapatkan pelayanan yang baik. Maka dari itu, untuk menunjang keberhasilan pelayanan sebuah perpustakaan, mutlak dibutuhkan keterampilan yang baik yang harus dimiliki oleh pustakawan. Keterampilan berkomunikasi (communication skill) adalah kemampuan pustakawan untuk menjalin komunikasi yang baik antara pustakawan dengan pengguna perpustakaan yang sering dipergunakan dalam kegiatan memberikan jasa layanan perpustakaan (Murniaty, 2006:5).

Menurut DeVito dalam Komariah (2009:12) komunikasi interpersonal adalah komunikasi yang terjadi diantara dua orang yang telah memiliki hubungan yang jelas, yang terhubungkan dengan beberapa cara. Jadi komunikasi interpersonal misalnya komunikasi yang terjadi antara ibu dengan anak, dokter dengan pasen, dua orang dalam suatu wawancara, dsb. Definisi lain mengatakan bahwa komunikasi antarpribadi (interpersonal communication) adalah komunikasi antara orang-orang secara tatap muka, yang memungkinkan setiap pesertanya menangkap reaksi orang lain secara langsung, baik secara verbal ataupun nonverbal (Mulyana, 2005:73).

Kemampuan berkomunikasi interpersonal yang baik sangat diperlukan oleh manusia agar ia dapat menjalani berbagai kegiatan yang setiap hari ia lakoni misalnya saja dalam situasi yang formal seperti lingkungan kerja, apalagi ketika aktifitas kerja itu harus berhadapan langsung dengan orang lain dimana sebagian besar kegiatannya merupakan kegiatan komunikasi interpersonal. Profesi pustakawan adalah salah satu profesi yang termasuk dalam pemaparan di atas karena sebagian besar aktivitasnya adalah berhadapan langsung dan berkomunikasi dengan orang lain. Pustakawan yang profesional dituntut untuk mampu berkomunikasi interpersonal dengan baik dan efektif karena ia bertanggungjawab untuk menyediakan akses informasi yang seluas-luasnya kepada pemustaka. Keterampilan berkomunikasi, dalam hal ini komunikasi interpersonal sangat penting, karena dalam pekerjaannya pustakawan akan berhadapan langsung dengan para pengguna perpustakaan. Keterampilan pustakawan dalam melakukan komunikasi interpersonal yang efektif akan menentukan keberhasilan pustakawan dalam menjalankan tugasnya.

Menurut De Vito dalam Komariah (2009:28), keterampilan komunikasi interpersonal yang efektif yang harus dimiliki oleh pustakawan adalah sebagai berikut:

1. Empathy

Yaitu ikut merasakan apa yang orang lain rasakan tanpa kehilangan identitas diri sendiri. Melalui empathy kita bisa memahami baik secara emosi maupun secara intelektual apa yang pernah dialami oleh orang lain.

2. Supportiveness 
Komunikasi interpersonal akan efektif apabila tercipta suasana yang mendukung. Nuansa dukungan akan tercipta apabila proses komunikasi fleksibel dan tidak kaku. Jadi dalam proses penyampaian pesan gunakanlah kata-kata atau kalimat yang deskriptif dan tidak memberikan penilaian, kemudian tunjukkan bahwa masing-masing pelaku komunikasi bersedia mendengarkan pendapat lawan bicara dan bahkan mengubah pendapat kalau memang diperlukan.

3. Positiveness

Dalam komunikasi interpersonal yang efektif para pelaku komunikasi harus menunjukkan sikap yang positif dan menghargai keberadaan orang lain sebagai seseorang yang penting (stroking).

4. Equality

Maksudnya adalah penerimaan dan persetujuan terhadap orang lain yang menjadi lawan bicara. Harus disadari bahwa semua orang bernilai dan memiliki sesuatu yang penting yang bisa diberikan pada orang lain. Kesetaraan dalam komunikasi interpersonal harus ditunjukan dalam proses pergantian peran sebagai pembicara dan pendengar.

5. Confidence

Para pelaku komunikasi interpersonal harus memilki rasa percaya diri secara sosial (social confidence).

6. Immediacy

Merujuk pada situasi adanya perasaan kebersamaan antara pembicara dan pendengar (oneness). Immediacy ditunjukan dengan sikap memperhatikan, menyenangi, dan tertarik pada lawan bicara dengan menunjukkannya secara verbal maupun non verbal.

7. Interaction management

Adalah kemampuan untuk mengontrol interaksi demi memuaskan kedua belah pihak pelaku komunikasi yang bisa dilakukan dengan mengatur kapan waktunya untuk berbicara.

\section{Metode Penelitian}

Metode yang digunakan dalam penelitian ini adalah kualitatif deskriptif. Pengumpulan data dilakukan dengan melakukan wawancara dengan pustakawan. Butir pertanyaan untuk pedoman wawancara terdiri dari 7 (tujuh) poin, yaitu Emphaty, Supportiveness, Positiveness, Equality, Confidence, Immediacy dan Interaction management yang dikemukakan oleh Vito, yang merupakan keterampilan komunikasi interpersonal yang efektif yang harus dimiliki oleh pustakawan. Karena keterbatasan penulis, wawancara dilakukan kepada seorang pustakawan.

\section{Hasil dan Pembahasan}

\subsection{Emphaty}

Dalam melaksanakan tugasnya sebagai pustakawan, informan sangat memahami bahwa kebutuhan informasi pemustaka menjadi hal yang penting untuk diketahui dan dipenuhi. Informan akan merasa kesusahan (sedih) ketika mengetahui informasi yang diinginkan oleh 
pemustaka tidak dapat ditemukan. Namun tanggungjawab sebagai pemberi informasi selalu tertanam sehingga ketika ada pemustaka yang tidak dapat menemukan informasi yang dia cari, maka informan akan bertanya dan membantu mencarikan literatur yang diinginkan oleh pemustaka. Bahkan secara berkala pustakawan menyebarkan instrumen yang berisi kebutuhan pemustaka mengenai koleksi yang diinginkan. Dalam melakukan penyebaran instrumen tersebut, pustakawan juga melakukan komunikasi dengan pemustaka, hal ini dilakukan untuk menjaga hubungan harmonis dengan pemustaka dan juga agar pustakawan lebih mudah untuk mengetahui kebutuhan informasi pemustaka.

\subsection{Supportiveness}

Pustakawan berupaya untuk dapat berkomunikasi dengan baik dengan pemustaka, tujuannya tidak lain adalah untuk memberikan pelayanan terbaik. Pustakawan sering sekali bersikap ramah dan selalu menyapa pemustaka yang datang ke perpustakaan, bahkan tak lupa ketika pemustaka sudah selesai dengan aktifitas mereka di perpustakaan, pustakawan mengucapkan rasa terimakasih karena telah berkunjung. Hal tersebut dilakukan agar pemustaka merasa addicted untuk selalu ke perpustakaan. Namun dalam upaya membangun komunikasi dan hubungan baik tersebut, pustakawan tidak kemudian mengesampingkan aturan-aturan yang berlaku di perpustakaan. Ketika ada pertanyaan tentang apakah pustakawan fleksibel dengan menerapkan aturan di perpustakaan sehingga dapat membuat pemustaka nyaman, pustakawan tidak setuju dengan hal tersebut. Menurutnya, setiap perpustakaan tentu memiliki aturan dan SOP untuk ditaati.

\subsection{Positiveness}

Sikap positif serta selalu menghargai kedatangan pemustaka sebagai seseorang yang penting (stroking) harus selalu dilakukan oleh pustakawan. Sikap menghargai tersebut ditunjukkan dengan selalu menyapa pemustaka dengan senyuman dan sapaan yang penuh kehangatan. Pikiran positif selalu dijaga, dengan tidak terlalu menaruh curiga kepada pemustaka ketika beraktifitas di perpustakaan. Menurut pustakawan, sikap yang selalu curiga justru akan mendatangkan hubungan yang tidak hangat dengan pemustaka, dan hal tersebut dapat menjadi penyebab pemustaka enggan untuk datang kembali ke perpustakaan. Pustakawan selalu mencoba adil kepada seluruh pemustaka tanpa terkecuali dan tanpa pandang bulu, tidak ada pemustaka yang diistimewakan maupun dikesampingkan. Hal tersebut sesuai dengan apa yang termaktub di dalam Undang-Undang Nomor 43 Tahun 2007 bahwa setiap orang berhak untuk mendapatkan akses informasi.

\subsection{Equality}

Pustakawan selalu siap membantu pemustaka tanpa bersikap menggurui terlebih sampai membuat mereka merasa bodoh atau tidak tahu apa-apa. Pustakawan selalu mendengarkan dengan baik apa yang sedang disampaikan oleh pemustaka, tanpa menyela pembicaraan. Penyampaian jawaban yang baik juga dilakukan agar pemustaka tidak merasa rendah diri. 


\subsection{Confidence}

Kebanggaan menyandang profesi pustakawan ternyata membuat pustakawan terlihat antusias dan siap bekerja. Dengan selalu mengikuti perkembangan isu terbaru dalam dunia kepustakawanan, pustakawan selalu percaya diri untuk menghadapi pertanyaan dari pemustakan. Namun menurut pustakawan, percaya diri yang timbul tidak kemudian membuat tinggi hati, justru sikap low profile yang coba untuk ditunjukkan.

\subsection{Interaction management}

Interaction management merupakan mengontrol komunikasi dengan mengatur kapan waktunya untuk berbicara agar kedua belah pihak merasa puas. Pustakawan merasa selalu membuat percakapan berjalan dengan lancar, sehingga pemustaka tidak merasa takut atau malu bertanya,

\section{Simpulan}

Berdasarkan pada hasil analisis tentang keterampilan komunikasi personal pustakawan di Dinas Kearsipan dan Perpustakaan Provinsi Kepulauan Bangka Belitung dapat disimpulkan bahwa pustakawan telah memiliki keterampilan komunikasi interpersonal dengan pemustaka. Komunikasi interpersonal tersebut dilakukan dengan menunjukkan sikap empati, menjaga hubungan harmonis sehingga terbangun komunikasi yang baik, menghargai pemustaka dengan tidak mencurigai aktifitas mereka di perpustakaan, menjadi pribadi yang percaya diri.

\section{Daftar Pustaka}

Mulyana, Deddy. 2005. Ilmu Komunikasi: Suatu Pengantar. Bandung: Remaja Rosda Karya.

Murniaty. 2006. "Membangun Image Pustakawan Melalui Keterampilan Berkomunikasi”. Karya Tidak Diterbitkan. Medan: USU.

Komariah, Neneng. 2009. "Keterampilan Komunikasi Interpersonal Bagi Pustakawan”. Tesis Tidak Diterbitkan. Bandung: Fakultas Komunikasi Universitas Padjajaran.

Soeatminah. 1992. Perpustakaan, Kepustakawanan dan Pustakawan. Yogyakarta: Kanisius.

Tim Penyusun Kamus. 2007. Kamus Besar Bahasa Indonesia. Ed.3. Cet.3. Jakarta: Balai Pustaka. 